\title{
Hydroxycinnamic acids in the raw material of hybrid bearded iris
}

\author{
A. V. Krechun $\mathbb{D}^{* 1, \mathrm{D}}$, O. O. Mykhailenko ${ }^{1, \mathrm{C}}$, V. M. Kovalov ${ }^{1, \mathrm{~F}}$, Yu. V. Buidin ${ }^{2, \mathrm{E}}$, \\ T. P. Osolodchenko $0^{3, E}$
}

${ }^{1}$ National University of Pharmacy, Kharkiv, Ukraine, ${ }^{2} \mathrm{M}$. M. Gryshko National Botanical Garden of the National Academy of Sciences of Ukraine, Kyiv, ${ }^{3}$ State Institution “I. Mechnikov Institute of Microbiology and Immunology National Academy of Medical Sciences of Ukraine", Kharkiv

A - research concept and design; B - collection and/or assembly of data; C - data analysis and interpretation; D - writing the article;

$\mathrm{E}$ - critical revision of the article; $\mathrm{F}$ - final approval of the article

Key words: iris, hydroxycinnamic acids, antimicrobial activity, chromatography.

\section{Zaporozhye} medical journa 2020; 22 (2), 256-260

*E-mail: ana2017krechun@ gmail.com
Representatives of Iris genus (Iridaceae) are widespread in almost all continents. According to the literature data, Iris species accumulate secondary metabolites such as flavonoids, isoflavonoids, xanthones, coumarins, hydroxycinnamic acids, saponins, tannins, vitamins, organic acids.

The aim of this work was the establishment of the qualitative and quantitative composition of hydroxycinnamic acids in the raw materials of iris hybrid varieties, as well as to establish the antimicrobial activity of the dry extracts and isolation of individual compounds.

Materials and methods. The objects of study were the leaves and rhizomes of the standard dwarf bearded iris (SDB). The substances were isolated by column chromatography, nature was established by physical and physicochemical methods of analysis (UV-, IR spectroscopy, TLC). Antibacterial activity was determined by the agar well diffusion method in vitro.

Results. Hydroxycinnamic acids were identified in the iris raw materials by paper chromatography. The spectrophotometric method established of the hydroxycinnamic acid content in the recalculation on chlorogenic acid - was from $0.79 \%$ to $2.83 \%$. The dry extracts of the leaves and rhizomes of $I$. hybrida "Little Dream" at a $1 \%$ concentration have shown moderate inhibitory activity for Gram-positive bacteria and fungi. For the first time from the rhizomes of Iris hybrida "Indian Pow Waw" were isolated caffeic, chlorogenic, neochlorogenic, ferulic acids by the column chromatography and their structures were determined by spectral methods.

Conclusions. The content of hydroxycinnamic acids in the samples varies from $0.79 \%$ to $2.83 \%$. The antimicrobial activity of the dry extracts of $I$. hybrida "Little Dream" leaves and rhizomes was established. For the first time from the rhizomes of Iris hybrida "Indian Pow Waw" were isolated 4 derivatives of hydroxycinnamic acid. The results of the study show the prospects for the use of cultivated varieties of irises as a source of hydroxycinnamic acids.

\section{Ключові слова:} півники, гіАроксикоричні кислоти, антибактеріальна активність, хроматографія.

Запорізький медичний журнал. 2020. T. 22, № 2(119). C. 256-260

\section{Гідроксикоричні кислоти в сировині гібридних бородатих півників}

\section{А. В. Кречун, О. О. Михайленко, В. М. Ковальов, Ю. В. Буйдін, Т. П. Осолодченко}

Представники роду Iris (Iridaceae) поширені майже на всіх континентах. За даними фахової літератури, види півників накопичують вторинні метаболіти, як-от флавоноїди, ізофравоноїди, ксантони, кумарини, гідроксикоричні кислоти, сапоніни, таніни, вітаміни, органічні кислоти.

Мета роботи - встановлення якісного та кількісного складу гідроксикоричних кислот у сировині гібридних сортів півників, а також антимікробної активності сухих екстрактів і виділення індивідуальних речовин.

Матеріали та методи. Об'єкти дослідження - листя, кореневища стандартних карликових бородатих півників (SDB). Речовини виділяли методом колонкової хроматографії, природу встановлювали фізичними та фізико-хімічними методами аналізу (УФ-, ІЧ-спектроскопія, ТШХ). Антибактеріальну активність визначали методом дифузії в агар in vitro.

Результати. Гідроксикоричні кислоти ідентифіковані в сировині півників методом хроматографії. Спектрофотометричним методом встановили вміст гідроксикоричних кислот у перерахунку на хлорогенову кислоту - від 0,79 \% до 2,83 \%. Сухі екстракти листя, кореневищ I. hybrida «Little Dream» при концентрації 1 \% показали помірну інгібувальну активність на грампозитивні бактерії та гриби. Уперше колонковою хроматографією з кореневищ Iris hybrida «Indian Pow Waw» виділені кавова, хлорогенова, неохлорогенова, ферулова кислоти, а їхня структура встановлена інструментальними методами.

Висновки. Вміст гідроксикоричних кислот у зразках варіює від 0,79 \% до 2,83 \%. Встановили антимікробну активність сухих екстрактів листя та кореневищ I. hybrida «Little Dream». Уперше з кореневищ Iris hybrida «Indian Pow Waw» виділили 4 похідні гідроксикоричної кислоти. Результати дослідження свідчать про перспективність використання культивованих сортів півників як джерела гідроксикоричних кислот.

\section{Гидроксикоричные кислоты в сырье гибридных бородатых ирисов}

\section{А. В. Кречун, О. А. Михайленко, В. Н. Ковалёв, Ю. В. Буйдин, Т. П. Осолодченко}

Представители рода Iris (Iridaceae) распространены почти на всех континентах. По данным научной литературы, виды ирисов накапливают вторичные метаболиты, такие как флавоноиды, изофлавоноиды, ксантоны, кумарины, гидроксикоричные кислоты, сапонины, танины, витамины, органические кислоты.

Цель работы - установление качественного и количественного состава гидроксикоричных кислот в сырье гибридных сортов ирисов, а также установление антимикробной активности сухих экстрактов и выделение индивидуальных веществ. 
Материалы и методы. Объекты исследования - листья и корневища стандартных карликовых бородатых ирисов (SDB). Вещества выделяли методом колоночной хроматографии, природу устанавливали физическими и физико-химическими методами анализа (УФ-, ИК-спектроскопия, ТСХ). Антибактериальную активность определяли методом диффузии в агар in vitro.

Результаты. Гидроксикоричные кислоты идентифицированы в сырье ирисов методом хроматографии. Спектрофотометрическим методом установлено содержание гидроксикоричных кислот в пересчете на хлорогеновую кислоту - от 0,79 \% до 2,83 \%. Сухие экстракты листьев и корневищ I. hybrida «Little Dream» при концентрации 1 \% показали умеренную ингибирующую активность в отношении грамположительных бактерии и грибов. Впервые методом колоночной хроматографии из корневищ Iris hybrida «Indian Pow Waw» выделены кофейная, хлорогеновая, неохлорогенова, феруловая кислоты, а их структура установлена инструментальными методами.

Выводы. Содержание гидроксикоричных кислот в образцах варьирует от 0,79 \% до 2,83 \%. Установлена антимикробная активность сухих экстрактов листьев и корневищ I. hybrida «Little Dream». Впервые из корневищ Iris hybrida «Indian Pow Waw» выделены 4 производные гидроксикоричной кислоты. Результаты исследования свидетельствуют о перспективности использования культивируемых сортов ирисов как источника гидроксикоричных кислот.

The genus Iris (Iridaceae) has long been known as ornamental, honey-bearing and medicinal plants, the number of which covers more than 300 species [1]. Iris count more than 4.000 hybrid varieties, distributed not only in Ukraine but also in Europe, Central, and Eastern Asia, North and South America [2]. According to the literature, iris accumulate secondary metabolites - flavonoids, isoflavonoids, xanthones, coumarins, hydroxycinnamic acids, saponins, tannins, vitamins, organic acids [3]. In folk medicine, the rhizomes of iris have been used as an anti-inflammatory, antibacterial, laxative, analgesic agent [4]. Based on these data, the phytochemical study of iris has a practical interest in the modern pharmacy.

As a result of the previous study, the hydroxycinnamic acids were identified in the leaves and rhizomes of Iris hungarica, and their quantitative content was established $2.6 \%$ in the rhizomes and $4.7 \%$ - in the leaves [5].

The hydroxycinnamic acids belong to the class of phenolic compounds, were found in almost all plants in the free acids form, their dimers, and esters. The pharmacological activity of this group of biologically active substances is being studied, there is information about choleretic, antimicrobial, tuberculostatic, antioxidant, hepatoprotective activity $[6,7]$. The caffeic acid and its derivatives (chlorogenic and isomers), which have an anti-inflammatory and choleretic effect, are most common in nature [8]. Ferulic acid is found in plant cells. Together, chlorogenic, ferulic, caffeic, coumaric acids have a hypoazotemic effect, enhance kidney function and stimulate the anti-toxic function of the liver [9].

\section{Aim}

Continuing the study of Iris genus plants the aim was to establish the qualitative and quantitative composition of hydroxycinnamic acids in the raw materials of iris hybrid varieties, as well as to establish the antimicrobial activity of dry extracts and isolation individual compounds.

\section{Materials and methods}

Experimental. For determination of the received substances structures physical and physicochemical methods of analysis (UV-, IR spectroscopy, chromatography in a thin layer of sorbent (Silufol UV-254 plates; silica gel $60 \mathrm{~F}_{254}$ TLC plates), column chromatography on silica gel (230-400 mesh, Merck, Germany) were used. Melting point (MP) was determined on the Kofler block (Franz Kustner nqch
K:G:Dresden; N.K.70/3314k). The substances were dried on rotary evaporator "Heidolph 2 WB eco, Laborata400 efficient" (Germany). UV-absorption spectra and optical density were recorded with a spectrophotometer module of Thermo Scientific Evolution 60S UV (СШA) in cells with a layer thickness of $10 \mathrm{~mm}$. IR-spectra were recorded on the instrument Tensor 27, UR20 (GDR) in the tablets of potassium bromide.

Plant material. The objects of the study were leaves and rhizomes of varietal bearded irises, harvested in the vegetation phase in 2017 in the M. M. Gryshko National Botanical Gardens of the National Academy of Sciences of Ukraine (Kyiv, Ukraine): Iris hybrida hort. "Bright white", Iris hybrida hort. "Indian Pow Waw", Iris hybrida hort. "Galleon Gold", Iris hybrida hort. "Mini Dynamo", Iris hybrida hort. "Little Dream". These varieties belong to the group of standard dwarf bearded irises, which are widely cultivated and valuable for their high decorative properties. The objects of research were identified by one of the authors (Yu. V. Buidin)

Plant material was dried to air-dry condition, stored in a cool well-ventilated place. The raw materials were crushed to a particle size of 2-3 $\mathrm{mm}$ for qualitative, quantitative analysis and for the isolation of substances.

Qualitative analysis. Analytical samples of leaves and rhizomes of varieties iris were crushed to $2-3 \mathrm{~mm}$ particles, an extracting agent (70\% ethanol) was added in a ratio of $1: 10$, a reflux condenser was added and heated in a water bath at $90^{\circ} \mathrm{C}$ for 1 hour to obtain extracts. After cooling, the extracts were filtered through a paper folded filter. Qualitative analysis was performed by paper and thin-layer chromatography in the solvent systems of $15 \%$ acetic acid, $2 \%$ acetic acid.

On the chromatograms, the substances were detected by the characteristic fluorescence in UV light at a wavelength of $365 \mathrm{~nm}$ and $254 \mathrm{~nm}$. Ammonia vapors, $2 \%$ alcohol solution of aluminum chloride, $10 \%$ sodium/ potassium hydroxide solution, $5 \%$ alcohol solution of diazotized sulfanilic acid (diazo reactive) were used as developers, which allows obtaining zones with brighter and more characteristic fluorescence in UV light. The Rf of spots was also determined for the identification of substances and compared with standard samples of phenol carboxylic acids - chlorogenic, neoclorogenic, coffee, ferulic, cinnamic, hydroxycinnamic, p-coumaric.

Quantitative analysis. To establish the quantitative content of the amount of hydroxycinnamic acids in the leaves and rhizomes of varieties irises the spectrophotometry
Ключевые слова: ирисы, гиАроксикоричные кислоты, антибактериальная активность, хроматография.

\section{Запорожский} медицинский журнал. 2020. T. 22, № 2(119).

C. $256-260$ 
method was used ("Herb Egeronum Canadian" (TPM 42U-6/37-323-96) [10]: about 1.0 gram (an exact weight) of the crushed raw material was placed in a $200 \mathrm{ml}$ flask, 50 $\mathrm{ml}$ of $40 \%$ ethyl alcohol was added, a reflux condenser was added and heated in a water bath for 1 hour, maintaining a gentle boil. After cooling, the extract was filtered through a paper filter. $1 \mathrm{ml}$ of the obtained extract was transferred to a $50 \mathrm{ml}$ volumetric flask and the volume was adjusted to the mark with $20 \%$ ethyl alcohol. $20 \%$ ethyl alcohol was used as a compensation solution. Spectra were measured at a wavelength of $327 \mathrm{~nm}$. The content of hydroxycinnamic acids in terms of chlorogenic acid and absolutely dry raw materials was calculated by the formula, using the specific absorption rate of chlorogenic acid:

$$
X, \% \frac{A * 50 * 50 * 100}{531 * m_{n}^{*} 1 *(100-W)},
$$

where A: the optical density of the test solution; $m_{n}$ : sample weight, $g$; W: weight loss on drying, \%; 531: specific absorption rate of chlorogenic acid.

Isolation of individual compounds. Iris hybrida "Indian Pow Wow" raw material was used for the experiment, collected in the M. M. Gryshko National Botanical Garden in 2017. Air - dry raw materials (rhizomes) in the total mass of $1 \mathrm{~kg}$ were extracted with $70 \%$ ethyl alcohol $(10 \mathrm{~L})$. The extract $(8.5 \mathrm{~L})$ concentrated to a volume of $800-900 \mathrm{ml}$ and left for 24 hours to precipitate chlorophylls and gums $\left(5-10^{\circ} \mathrm{C}\right)$. The tar precipitate was filtered and washed by hot water $(0.5 \mathrm{~L})$. The resulting extract was evaporated and treated sequentially with chloroform, ethyl acetate, butanol. The fractions were evaporated until the solvents were removed.

The qualitative composition of the fractions was identified by paper and thin-layer chromatography. Chloroform and ethyl acetate extraction had a similar component composition, so they were combined. For this, the chloroform extraction was evaporated to a minimum amount, washed with $96 \%$ ethyl alcohol, and then treated with ethyl acetate.

The combined fraction was evaporated, mixed with $5 \mathrm{~g}$ of silica gel and applied to the column $(\mathrm{d}=4.5 ; \mathrm{h}=80)$. The substances were eluted with chloroform and a mixture of chloroform: ethanol with an increasing concentration of alcohol. 120 fractions were obtained.

The composition of all the obtained fractions was controlled by paper and thin-layer chromatography: solvent system BAW (n-butanol - acetic acid - water) $4: 1: 2,15 \%$ acetic acid, chloroform - methanol 8:2. Similar fractions were combined. In fractions 41-46 and 74-78 substances previously classified as phenol carboxylic acid derivatives were detected.

Spectral data

Caffeic acid. $\mathrm{C}_{9} \mathrm{H}_{8} \mathrm{O}_{4}$, yellow substance, mp 194$195^{\circ} \mathrm{C}$. UV $\lambda \max \left(\mathrm{C}_{2} \mathrm{H}_{5} \mathrm{OH}\right) \mathrm{nm}: 325,203$. Rf 0.32 (solvent system $-2 \%$ acetic acid). IR (KBr), v , $\mathrm{cm}^{-1}: 3400,3235$, $2975(\mathrm{OH}), 1647,1630$ (C = O), 1607, 1540 (Ar), 880, 860 (substituted benzene).

Chlorogenic acid. $\mathrm{C}_{16} \mathrm{H}_{18} \mathrm{O}_{9}, \mathrm{mp} 203-205^{\circ} \mathrm{C}$. UV $\lambda$ max $\left(\mathrm{C}_{2} \mathrm{H}_{5} \mathrm{OH}\right) \mathrm{nm}: 325,273$. Rf 0.66 (solvent system $-2 \%$ acetic acid); IR (KBr), v, cm ${ }^{-1}: 2970,2900,2780(\mathrm{OH})$, 1740-1710 (ester group), 1660, 1625 (C = O), 1605-1550 (Ar), 840 (substituted benzene).
Neochlorogenic acid. $\mathrm{C}_{16} \mathrm{H}_{18} \mathrm{O}_{9}$, amorphous solid; UV $\lambda \max \left(\mathrm{C}_{2} \mathrm{H}_{5} \mathrm{OH}\right) \mathrm{nm}: 325,300$. Rf 0.70 (solvent system $2 \%$ acetic acid).

Ferulic acid. $\mathrm{C}_{10} \mathrm{H}_{10} \mathrm{O}_{4}, \mathrm{mp} 168-170{ }^{\circ} \mathrm{C}$. UV $\lambda$ max $\left(\mathrm{C}_{2} \mathrm{H}_{5} \mathrm{OH}\right) \mathrm{nm}: 320,274$ should. Rf 0.43 (solvent system $2 \%$ acetic acid); IR (KBr), v: $3450 \mathrm{~cm}^{-1}$ (carbonic acid $\mathrm{OH}$ ), $1690 \mathrm{~cm}^{-1}(\mathrm{C}=\mathrm{O}), 1275 \mathrm{~cm}^{-1}$ and $1510 \mathrm{~cm}^{-1}$ (carboxylic acid C-O stretching), $1605 \mathrm{~cm}^{-1}$ (aromatic $\mathrm{C}=\mathrm{C}$ ) confirms the skeleton of ferulic acid.

Extraction procedure of plant for bioassay. To determine the antibacterial activity previously was obtained dry extracts from the leaves and rhizomes of irises. $100.0 \mathrm{~g}$ of crushed raw materials were placed in a round-bottom flask, poured $1000 \mathrm{ml}$ of solvent (distilled water), heated in a boiling water bath for 2 hours. The first portion of the extract was taken, after which $500 \mathrm{ml}$ of distilled water was added to the raw material and heated in a water bath for another 2 hours. The combined extract was filtered through a Buchner funnel and evaporated to dryness.

Antibacterial activity. According to the WHO recommendations, antibacterial activity was determined by agar well diffusion method in vitro. The inoculum suspension was prepared using a Densi-La-Meter apparatus (PLIVA-Lachema, $540 \mathrm{~nm}$ ). The cultures were synchronized using low temperature $\left(4^{\circ} \mathrm{C}\right)$. The microbial load was 107 cells per $1 \mathrm{ml}$ of the medium and was determined according to the McFarland standard [11]. The 18-24 - hour culture of microorganisms was used for the test. Mueller-Hinton agar was used ("HIMedia Laboratories Pvt. Ltd India", India) for bacteria. The strains of Candida albicans were cultivated using Sabouraud agar ("HIMedia Laboratories Pvt. Ltd India", India). The standard medium was prepared according to the requirements of the manufacturer. When determining microorganisms' sensitivity to the samples of iris take into account zones of growth of bacteria strains. An alcoholic solution of chlorophyllipt at a concentration of $10 \mathrm{mg} / \mathrm{ml}$ was used as a reference drug (GNZLS "OZ").

Statistical data processing was carried out according to the requirements of the State Pharmacopoeia of Ukraine using software (Microsoft Office Excel 7.0) [12].

\section{Results}

Qualitative analysis. According to the results of qualitative reactions with alcoholic solutions of sodium hydroxide, aluminum chloride and diazoreactant on chromatograms with extracts Iris hybrida hort. "Bright white", Iris hybrida hort. "Indian Pow Waw", Iri hybrida hort. "Galleon Gold", Iris hybrida hort. "Mini Dynamo", Iris hybrida hort. "Little Dream" was found more than 8-21 substances of phenolic nature. At the same time, absorption zones with blue, violet, and blue-violet fluorescence characteristic of phenol carboxylic acids were identified.

Chromatograms differed in the number of spots, their chromatographic behavior, the color of the spots before and after their treatment in the UV light, the values of Rf.

According to the chromatographic behavior and comparison with the standards in the all iris varieties were identified caffeic, cinnamic, hydroxycinnamic, p-coumaric, fumaric, chlorogenic, and neoclorogenic acids (Table 1).

Quantitative analysis. The quantitative content of hydroxycinnamic acids in the leaves and rhizomes of varieties 
Table 1. The identification parameters of hydroxycinnamic acids in the raw materials of iris varieties

\begin{tabular}{|c|c|c|c|c|c|c|}
\hline \multirow{2}{*}{$\begin{array}{l}\text { Hydroxycinnamic } \\
\text { acids }\end{array}$} & \multicolumn{3}{|l|}{ UV fluorescence } & \multirow{2}{*}{$\begin{array}{l}\text { Rf } \\
\text { solvent system: } \\
2 \% \text { acetic acid }\end{array}$} & \multicolumn{2}{|c|}{ The type of the raw material, in which the acid was identified } \\
\hline & before treatment & $\begin{array}{l}\text { after treatment } \\
\mathrm{NH}_{3 \uparrow}\end{array}$ & $\begin{array}{l}\text { after treatment } \\
\text { with diazoreactive }\end{array}$ & & leaves & rhizomes \\
\hline chlorogenic & blue & blue - green & red - brown & 0.66 & in the all objects & in the all objects \\
\hline neochlorogenic & blue & blue - green & dark - red & 0.70 & in the all objects & in the all objects \\
\hline ferulic & blue & blue-violet & red-brown & 0.43 & $\begin{array}{l}\text { I. hybrida "Galleon Gold" } \\
\text { I. hybrida "Little Dream" } \\
\text { I. hybrida "Indian Pow Waw" }\end{array}$ & $\begin{array}{l}\text { I. hybrida "Galleon Gold" } \\
\text { I. hybrida "Little Dream" } \\
\text { I. hybrida "Indian Pow Waw" }\end{array}$ \\
\hline cinnamic & pale - blue & blue-violet & brown & 0.54 & in the all objects & in the all objects \\
\hline hydroxycinnamic & brown & brown & red-brown & 0.58 & in the all objects & in the all objects \\
\hline caffeic & pale-blue & bright - blue & red-brown & 0.32 & $\begin{array}{l}\text { I. hybrida "Bright white" } \\
\text { I. hybrida "Indian Pow Waw" }\end{array}$ & $\begin{array}{l}\text { I. hybrida "Mini Dynamo" } \\
\text { I. hybrida "Little Dream" }\end{array}$ \\
\hline p-coumaric & blue & blue-violet & dark - red & 0.48 & $\begin{array}{l}\text { I. hybrida "Bright white" } \\
\text { I. hybrida "Little Dream" }\end{array}$ & $\begin{array}{l}\text { I. hybrida "Bright white" } \\
\text { I. hybrida "Little Dream" }\end{array}$ \\
\hline
\end{tabular}

irises was established by the spectrophotometric method, the data are presented in Table 2.

Antibacterial activity. Hydroxycinnamic acids exhibit many pharmacological activities, including antibacterial. Based on the data obtained, in the leaves and rhizomes of $I$. hybrida "Little Dream" contains the maximum amount of hydroxycinnamic acids, antimicrobial activity was established by the method of diffusion into agar (Table 3).

\section{Discussion}

Fumaric acid was found in the leaves and rhizomes of I. hybrida "Galleon Gold", I. hybrida "Little Dream", I. hybrida "Indian Pow Waw"; n-coumaric - in the leaves and rhizomes of I. hybrida "Bright white", I. hybrida "Little Dream"; caffeicin the leaves I. hybrida "Bright white", I. hybrida "Indian Pow Waw", and in the rhizomes of I. hybrida "Mini Dynamo", I.hybrida "Little Dream". Chlorogenic, neochlorogenic, cinnamic and hydroxycinnamic acids were found in all objects.

The content of hydroxycinnamic acids in the samples varies from $0.79 \%$ to $2.83 \%$. The smallest content in the rhizomes is from $0.79 \%$ to $2.49 \%$, which is due to the peculiarities of the metabolism of herbaceous plants. However, it should be noted that in the rhizomes of $I$. hybrida "Little Dream" the content of hydroxycinnamic acids is relatively high $-2.49 \%$. The largest amount of hydroxycinnamic acids is observed in the leaves of $I$. hybrida "Little Dream" (2.83\%), I. hybrida "Galleon Gold" (2.82 \%), I. hybrida "Mini Dynamo" (2.55\%); the smallest is in the leaves of I. hybrida "Indian Pow Waw".

The data in Table 3 indicate that dry extracts of $I$. hybrida "Little Dream" leaves and rhizomes exhibit antibacterial activity against Staphylococcus aureus, Escherichia coli, Basillus subtilis, Candida albicans and a weak effect on Proteus vulgaris and Pseudomonas aeruginosa.

\section{Conclusions}

1. In the raw materials of 5 dwarf bearded irises varieties, hydroxycinnamic acids were identified.

2. The quantitative content of hydroxycinnamic acids in terms of chlorogenic acid was established. It is noted that hydroxycinnamic acids accumulate in larger amounts in the leaves of irises.

3. In I. hybrida "Little Dream" raw materials the content of hydroxycinnamic acids is the highest: $2.49 \%$ - in rhizomes and $2.83 \%$ - in leaves.
Table 2. The content of hydroxycinnamic acids in the raw material of varieties iris in terms of chlorogenic acid

\begin{tabular}{l|l|l}
\multicolumn{2}{l}{ The hydroxycinnamic acids content, $\%$} & \multirow{2}{*}{ Varieties } \\
\cline { 1 - 2 } leaves & rhizomes & \\
\cline { 1 - 2 } $2.82 \pm 0.03$ & $0.79 \pm 0.09$ & I. hybrida "Galleon Gold" \\
$2.83 \pm 0.07$ & $2.49 \pm 0.11$ & I. hybrida "Little Dream" \\
\cline { 1 - 2 } $2.44 \pm 0.10$ & $1.25 \pm 0.07$ & I. hybrida "Bright white" \\
$2.55 \pm 0.13$ & $1.77 \pm 0.08$ & I. hybrida "Mini Dynamo" \\
\hline $1.14 \pm 0.08$ & $0.97 \pm 0.12$ & I. hybrida "Indian Pow Waw" \\
\hline
\end{tabular}

Table 3. The activity of dry extracts of $I$. hybrida "Little Dream" leaves and rhizomes to microorganisms

\begin{tabular}{|l|l|l|l|l|}
\hline \multirow{2}{*}{ Microorganism strains } & \multicolumn{3}{l}{$\begin{array}{l}\text { The diameters of the growth inhibition zones at } 1 \% \\
\text { concentration, } \mathrm{mm}\end{array}$} \\
\cline { 2 - 5 } & leaves & rhizomes & $\begin{array}{l}\text { reference } \\
\text { drug }\end{array}$ & control \\
\hline Staphylococcus aureus ATCC 25923 & $17.66 \pm 0.10$ & $16.66 \pm 0.08$ & $17.63 \pm 0.11$ & growth \\
\hline Escherichia coli ATCC 25922 & $16.00 \pm 0.08$ & $15.66 \pm 0.13$ & $16.20 \pm 0.09$ & growth \\
\hline Proteus vulgaris ATCC 4636 & $14.66 \pm 0.12$ & $13.66 \pm 0.08$ & $14.34 \pm 0.12$ & growth \\
\hline Pseudomonas aeruginosa ATCC 27853 & $14.66 \pm 0.15$ & $13.00 \pm 0.14$ & $14.85 \pm 0.10$ & growth \\
\hline Basillus subtilis ATCC 6633 & $18.66 \pm 0.07$ & $17.00 \pm 0.09$ & $18.40 \pm 0.13$ & growth \\
\hline Candida albicans ATCC 653/885 & $17.00 \pm 0.10$ & $16.00 \pm 0.13$ & $17.63 \pm 0.09$ & growth \\
\hline
\end{tabular}

4. The antimicrobial activity of the dry extracts of I. hybrida "Little Dream" leaves and rhizomes was established: the preparations are highly sensitive to Staphylococcus aureus, Escherichia coli, Basillus subtilis, Candida albicans; weak activity on Proteus vulgaris and Pseudomonas aeruginosa.

5. The method of column chromatography was used to isolate 4 substances, derivatives of phenol carboxylic acids: caffeic, chlorogenic, neochlorogenic, ferulic acids, the structure of which was proved by spectral methods of analysis.

6 . The results of the study show the prospects for the use of cultivated varieties of irises as a source of hydroxycinnamic acids.

Conflicts of interest: authors have no conflict of interest to declare. Конфмікт інтересів: відсутній.

Надійшла Ао редакції / Received: 10.07.2019

Після Аоопрацювання / Revised: 04.09.2019

Прийнято Ао Аруку / Accepted: 27.09.2019 
Information about authors:

Krechun A. V., Postgraduate student of the Department of Pharmacognosy, National University of Pharmacy, Kharkiv, Ukraine.

ORCID ID: 0000-0001-5545-9415

Mykhailenko 0. O., PhD, Assistant Professor of the Department of Botany, National University of Pharmacy, Kharkiv, Ukraine. Kovalov V. M., PhD, DSc, Professor of the Department of Pharmacognosy, National University of Pharmacy, Kharkiv, Ukraine.

Buidin Yu. V., PhD, Head of the Department of Flower and Ornamental Plants, M. M. Gryshko National Botanical Garden of the National Academy of Sciences of Ukraine, Kyiv. Osolodchenko, T. P., PhD, State Institution “I. Mechnikov Institute of Microbiology and Immunology National Academy of Medical Sciences of Ukraine", Kharkiv.

\section{Відомості про авторів:}

Кречун А. В., аспірант каф. фармакогнозії, Національний фармацевтичний університет, м. Харків, Україна.

Михайленко 0. О., канА. фарм. наук, асистент каф. ботаніки, Національний фармацевтичний університет, м. Харків, Україна. Ковальов В. М., А-р фарм. наук, професор каф. фармакогнозії, Національний фармацевтичний університет, м. Харків, Україна. Буйдін Ю. В., канА. біол. наук, зав. віААілу квітково-Аекоративних рослин, Національний ботанічний саА імені М. М. Гришка НАН України, м. Київ

Осолодченко Т. П., канА. біол. наук, АУ «Інститут мікробіологіі та імунології імені І. І. Мечникова НАМН України", м. Харків.

\section{Сведения об авторах:}

Кречун А. В., аспирант каф. фармакогнозии, Национальный фармацевтический университет, г. Харьков, Украина. Михайленко О. А., канА. фарм. наук, ассистент каф. ботаники, Национальный фармацевтический университет, г. Харьков, Украина.

Ковалев В. Н., А-р фарм. наук, профессор каф. фармакогнозии, Национальный фармацевтический университет, г. Харьков, Украина.

Буйдин Ю. В., канА. биол. наук, зав. отАелом цветочноАекоративных растений, Национальный ботанический саА имени Н. Н. Гришко НАН Украины, г. Киев.

ОсолоАченко Т. П., канА. биол. наук, ГУ "Институт микробиологии и иммунологии имени И. И. Мечникова НАМН Украины", г. Харьков.

\section{References}

[1] Wilson, C. A. (2011). Subgeneric classification inlrisre-examined using chloroplast sequence data. TAXON, 60(1), 27-35. https://doi. org/10.1002/tax.601004

[2] Goldblatt, P., \& Manning, J. C. (2008). The Iris family : natural history et classification. Timber Press.

[3] Mykchailenko, O. O., \& Kovalyov, M. V. (2016). Phenolic compounds of the genus Iris plants (Iridaceae). Česká a slovenská farmacie, 65(2), 70-77. https://www.researchgate.net/profile/Mikhailenko_Olga/ publication/304667804_Phenolic_compounds_of_the_genus_Iris_ plants Iridaceae/links/5922f4bca6fdcc4443f7756d/Phenolic-compounds-of-the-genus-lris-plants-lridaceae.pdf

[4] Tikhomirova, L. I., Bazarnova, N. G., Mikushina, I. V., \& Dolganova, Z. V. (2015). Farmakologo-biokhimicheskoe obosnovanie prakticheskogo ispol'zovaniya nekotorykh predstavitelei roda Iris L.(obzor) [Farmacol-biochemical study of practical use of some members of the genus Iris L. (overview)]. Khimiya rastitel'nogo syr'ya, (3), 25-34. https://doi. org/10.14258/jcprm.201503837 [in Russian].

[5] Krechun, A. V., Mykhailenko, O. O., \& Kovalyov, V. M. (2016). Organic and hydroxycinnamic acids of Iris hungarica. In R. T. Tulyaganov, S. N. Aminov, \& N. T. Farmanova (Eds.). Aktual'nye voprosy obrazovaniya, nauki i proizvodstva v farmatsii: Materialy respublikanskoi nauchno-prakticheskoi konferentsii (s mezhdunarodnym uchastiem) (pp. 6-7). Tashkent.

[6] Cai, Y., Luo, Q., Sun, M., \& Corke, H. (2004). Antioxidant activity and phenolic compounds of 112 traditional Chinese medicinal plants associated with anticancer. Life Sciences, 74(17), 2157-2184. https:// doi.org/10.1016/.l.lfs.2003.09.047

[7] Tsimogiannis, D., \& Oreopoulou, V. (2019). Classification of Phenolic Compounds in Plants. In R. R. Watson (Ed.). Polyphenols in Plants. Isolation, Purification and Extract Preparation (2nd ed., pp. 263-284). Academic Press. https://doi.org/10.1016/B978-0-12-813768-0.00026-8
[8] dos Santos, M. D., Almeida, M. C., Lopes, N. P., \& de Souza, G. E. P. (2006). Evaluation of the Anti-inflammatory, Analgesic and Antipyretic Activities of the Natural Polyphenol Chlorogenic Acid. Biological \& Pharmaceutical Bulletin, 29(11), 2236-2240. https://doi.org/10.1248/ bpb.29.2236

[9] Matkowski, A., Jamiolkowska-Kozlowska, W., \& Nawrot, I. (2013). Chinese Medicinal Herbs as Source of Antioxidant Compounds - Where Tradition Meets the Future. Current Medicinal Chemistry, 20(8), 9841004. https://doi.org/10.2174/092986713805288888

[10] State Enterprise Ukrainian Scientific Pharmacopoeial Center of Medicines Quality. (2008, February 1). Derzhavna Farmakopeia Ukrainy. Dopovnennia 2 [The State Pharmacopoeia of Ukraine] (1st ed., Suppl. 2). Kharkiv: Naukovo-ekspertnyi farmakopeinyi tsentr. [in Ukrainian]

[11] McFarland, J. (1907). The nephelometer: an instrument for estimating the number of bacteria in suspensions used for calculating the opsonic index and for vaccines. The Journal of the American Medical Association, XLIX(14), 1176-1178. https://doi.org/10.1001/ jama.1907.25320140022001f

[12] State Enterprise Ukrainian Scientific Pharmacopoeial Center of Medicines Quality. (2004, April 1). Derzhavna Farmakopeia Ukrainy. Dopovnennia 1 [The State Pharmacopoeia of Ukraine] (1st ed., Suppl. 1). Kharkiv: Naukovo-ekspertnyi farmakopeinyi tsentr. [in Ukrainian] 